\title{
An overview of the health status of migrants in France, in relation to their dietary practices
}

\author{
Nicole Darmon ${ }^{1 *}$ and Myriam Khlat ${ }^{2}$ \\ ${ }^{1}$ Institut National de la Santé et de la Recherche Médicale/Institut Scientifique et Technique de la Nutrition et de \\ I'Alimentation, 5 rue du Vert Bois, 75003-Paris, France: ${ }^{2}$ Institut National d'Etudes Démographiques, \\ 133 Bd Davout, 75980-Paris cedex 20, France
}

\begin{abstract}
Objective: To review studies on the morbidity, mortality and nutrition of migrant populations in France.

Design: A systematic search of the bibliographic database Medline, and direct contact with associations and institutions concerned with migrants' health.

Results: In France, as in other host countries, migrants belong to the lowest socioeconomic strata. They have on average better health and lower mortality than the local-born population. Health benefits are particularly noticeable in Mediterranean men, especially for affluence-related diseases such as cancer and cardiovascular diseases. North African men smoke as heavily as the local-born of the same occupational categories, and yet their mortality rates from lung cancer are notably lower. Such a paradox may be the result of a synergy between different phenomena such as the selection of the fittest applicants for immigration and the maintenance of healthy lifestyles from the countries of origin. In contrast, migrant women do not enjoy the same health advantages, possibly because they are less likely to be selected on the basis of their health and because they are often non-working. Adult migrants from southern Europe and North Africa report dietary practices consistent with the typical Mediterranean diet, which is renowned for its positive effects on health. Conclusions: The diet of Mediterranean adults living in France may partly explain the low rates of chronic diseases and high adult life expectancy observed in migrant men from northern Africa. Information about their diets might provide clues for the design of nutritional education campaigns aimed at low-income people.
\end{abstract}

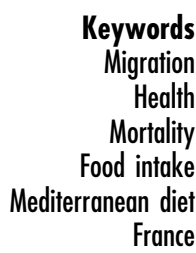

France
Migrants studies have long been popular in epidemiology, because they shed some light on the relative importance of the environment and genetic make-up of populations in shaping health disparities between countries $^{1,2}$. Given their unfavourable social background in most countries, migrants are expected to be at higher risk of morbidity and mortality, particularly from obesity- and smoking-related disorders ${ }^{3,4}$, and yet numerous findings contradict this expectation ${ }^{5-7}$. The maintenance of traditional behaviours, such as healthier dietary habits and greater family support may protect migrants from the diseases related to affluence prevalent in their host countries ${ }^{8,9}$. In this paper, we address the possibility that such a paradox also exists in France, and we discuss the potential role of nutrition in explaining health disparities between migrants and local-born populations.

Although France is traditionally a country of immigration, studies on health and health-related behaviours of migrants are to date scarce. The paucity of data might be related to the important methodological problems raised by migrants studies ${ }^{10}$. It has also been attributed to political reasons, i.e. concern that data on health risks and the costs of health care in migrants might be used to their detriment, and to conceptual reasons, whereby the differences between migrants and local-born populations would be mainly attributable to socio-economic differences $^{11}$. The studies published on the morbidity and mortality of migrant populations in France are reviewed, as well as data on their dietary patterns and nutritional status. A systematic search of the bibliographic database Medline was completed by contacting associations, universities and institutions concerned with migrants' socio-economic conditions or health, because unreferenced reports constitute a great part of the available information on the subject. 
Table 1 National data on morbidity of migrants in France

\begin{tabular}{|c|c|c|c|c|}
\hline $\begin{array}{l}\text { Ref. } \\
\text { number }\end{array}$ & $\begin{array}{l}\text { Study period, type of study } \\
\text { and study size }\end{array}$ & $\begin{array}{c}\text { Type of data, design } \\
\text { and methods }\end{array}$ & $\begin{array}{l}\text { Migrant groups and } \\
\text { comparison group }\end{array}$ & $\begin{array}{l}\text { Main results for migrants } \\
\text { (i.e. statistically significant) }\end{array}$ \\
\hline 25 & $\begin{array}{l}1988-1991 \\
\text { Population-based interview } \\
\text { survey of a representative } \\
\text { sample of households } \\
\text { affiliated with the national } \\
\text { social insurance scheme } \\
(29,266 \text { individuals })\end{array}$ & $\begin{array}{l}\text { Disability and vital } \\
\text { prognosis indicators, } \\
\text { health care utilization, } \\
\text { health insurance coverage, } \\
\text { with age standardization }\end{array}$ & $\begin{array}{l}\text { Foreigners or migrants } \\
\text { naturalized French } \\
\text { (together) vs. French } \\
\text { people born in France }\end{array}$ & $\begin{array}{l}\text { Better health status; } \\
\text { lower health care utilization } \\
\text { and lower health insurance } \\
\text { coverage }\end{array}$ \\
\hline 29 & $\begin{array}{l}1991-1992 \\
\text { Population-based interview } \\
\text { survey of a representative } \\
\text { sample of households } \\
\text { (10,000 households) }\end{array}$ & $\begin{array}{l}\text { Reported morbidity, } \\
\text { health care utilization, } \\
\text { tobacco consumption, } \\
\text { body mass index, } \\
\text { with adjustment for age } \\
\text { and occupational status }\end{array}$ & $\begin{array}{l}\text { Households whose heads } \\
\text { were from North Africa } \\
\text { vs. households whose } \\
\text { heads were of French } \\
\text { nationality }\end{array}$ & $\begin{array}{l}\text { Fewer illnesses ( }-33 \% \text { for men, } \\
\text { and }-16 \% \text { for women). } \\
\text { Protection from cardiovascular } \\
\text { diseases for men }(-68 \%) \text {. } \\
\text { Increased prevalence of endocrine } \\
\text { and metabolic diseases }(+39 \%) \\
\text { and of obesity (RR }=2.21) \\
\text { for women }\end{array}$ \\
\hline 27 & $\begin{array}{l}1978-1998 \\
\text { National AIDS register } \\
\text { (46,973 AIDS cases, } \\
\text { including } 6571 \text { cases among } \\
\text { foreigners) }\end{array}$ & $\begin{array}{l}\text { Mandatory notifications of } \\
\text { AIDS cases by nationality } \\
\text { related to population data, } \\
\text { with age standardization }\end{array}$ & $\begin{array}{l}\text { Eight groups of } \\
\text { nationalities vs. French }\end{array}$ & $\begin{array}{l}\text { Cumulative incidence rate } \\
\text { twice as high among foreigners } \\
\text { compared with French, with } \\
\text { highest risks among sub-Saharan } \\
\text { Africans and Haitians }\end{array}$ \\
\hline
\end{tabular}

\section{Origin and socio-demographic profile of migrant populations}

Immigration has a long history in Europe, particularly in France. Massive population moves, from neighbouring countries or from former French colonies into France, occurred during times of economic expansion and postwar rebuilding (Second Empire, 1920s, 1960s) generally followed by a stabilization of population flow during periods of economic recession (end of the 19th century, 1930s, 1970s).

According to the last published national census in 1990 , $6.2 \%$ of the population in France are of foreign nationality ('foreigners') and 7.2\% were born outside of France ('migrants' in the strict sense), being of foreign nationality or naturalized ${ }^{12}$. Migrant populations mainly originate from Mediterranean countries, with people from North Africa and southern Europe representing respectively 35\% and $32 \%$ of the foreigners. In 1990, Portuguese (17.7\%), Algerians (16.6\%) and Moroccans (13.9\%) formed the largest communities of foreigners, followed by Italians (7.8\%), Spanish (6.7\%) and Tunisians (4.7\%). Three other groups have increased during the last 20 years: eastern Europeans (mainly Turks and Yugoslavians, amounting to 7\%), sub-Saharan Africans (7\%) and Southeast Asians (mainly refugees from Laos, Vietnam and Cambodia, amounting to 3\%). Overall, the population of migrants is younger than the local-born population, with a difference in average age of 5 years for men and 8 years for women ${ }^{13}$. Although incoming migrants are now predominantly women and children, overall the migrant population is still composed mainly of men $(55 \%)^{13}$. More than one-third of the migrants have settled in Paris and its suburbs ${ }^{14}$.
Migrants generally belong to the lowest socio-economic social classes of France ${ }^{11}$. Consequently, various aspects of their living conditions are affected by poverty and/or precariousness of employment ${ }^{15,16}$, housing ${ }^{14,17}$, marital status ${ }^{13}$ and education ${ }^{18,19}$. Unknown numbers of migrants stay in France illegally or suffer from restrictions in social rights. Foreigners represent an important fraction (40\%) of the homeless in Paris ${ }^{20}$.

\section{Health status of migrants in France}

Twenty-four studies, which have included data on morbidity, mortality and/or nutrition of migrants, are reviewed in this section. The large population-based studies are summarized in Tables $1-3$.

\section{Utilization of preventive bealth services}

Studies have shown that, even after adjustment for socioeconomic factors, adult migrants ${ }^{21}$ and their children ${ }^{22}$ are less likely than the local-born population to engage in preventive medical measures. Pregnant women born in North Africa have less prenatal visits than women born in continental France, particularly if they do not speak French $^{23,24}$. Foreigners have a lower health insurance coverage and a lower health care utilization than their French peers ${ }^{25}$. An insufficient awareness of health risks and a poor understanding of health messages, due to cultural or language barriers, might be involved in this low utilization of preventive care.

\section{Morbidity}

In free health centres, which attract the most deprived migrants, often without health insurance coverage and/or legal status (referred to as 'sans papiers'), the frequencies 
Table 2 National data on mortality of migrants in France

\begin{tabular}{lllll}
\hline $\begin{array}{l}\text { Ref. } \\
\text { Number }\end{array}$ & $\begin{array}{c}\text { Study period, type of study } \\
\text { and study size }\end{array}$ & $\begin{array}{c}\text { Type of data, design } \\
\text { and methods }\end{array}$ & $\begin{array}{c}\text { Migrant groups and } \\
\text { comparison group }\end{array}$ & $\begin{array}{c}\text { Main results for migrants } \\
\text { (i.e. statistically significant) }\end{array}$ \\
\hline 30 & $\begin{array}{l}\text { 1974-1975 } \\
\text { Mortality statistics } \\
\text { (study size unknown) }\end{array}$ & $\begin{array}{l}\text { Age-specific death rates } \\
\text { and causes of death }\end{array}$ & $\begin{array}{l}\text { Foreigners } \\
\text { (by country of origin) } \\
\text { vs. French }\end{array}$ & $\begin{array}{l}\text { Lower mortality from } \\
\text { cardiovascular diseases, cancers } \\
\text { and alcohol-related diseases, } \\
\text { in males from Portugal and }\end{array}$ \\
& & & Algeria (recent migrations) \\
but not from Italy or Poland, \\
(ancient migrations). Higher \\
\end{tabular}

Representative samples of births (mother + child) $(10,419$ births in 1972 , 5285 births in 1981)

Mortality statistics (37,224 deaths)

1979-1985

Mortality statistics

(3,822,811 deaths)
1980-1982

Prenatal care, neonatal pathology

Death rates and causes of death for 1-14 and 15-24 years old

Cause-specific death rates. Poisson modelling with age, occupational status and place of residence

Deaths rates for cancer deaths by site. Poisson

1979-1985

Mortality statistics

(3,822,811 deaths including 816,096 deaths from cancer) occupational status and place of residence

\section{$34 \quad$ 1979-1991}

Mortality statistics ('more than 10,000 deaths')
Age-specific death rates, with adjustment for under-registration of deaths. Calculation of life expectancies. Poisson regression modelling of cause-specific death rates
Women born in North Africa, Higher stillbirth rate among Portugal, or other countries foreign women, especially (European or not) vs. French women born in those born in North Africa metropolitan France

Foreigners vs. French

Higher mortality for all causes in the two age groups and both sexes

People born in a foreign country vs. people born in France

Lower mortality from all causes $(-30 \%)$, more so among Mediterranean migrants than among eastern European, West African and Asian migrants

People born in Algeria, Low risks for most cancer Morocco, Tunisia and Egypt sites. High risks for certain vs. people born in France cancers such as nasopharynx and bladder

Moroccans born in

Lower mortality and higher life expectancy at birth for Moroccan men. Slightly higher mortality of women. Protection from cardiovascular diseases in men $(R R=0.71)$, from cancer in men $(R R=0.68)$ and women $(\mathrm{RR}=0.88$ ) Increased risk for diabetes in women $(\mathrm{RR}=2.49)$

Table 3 National data on diets of migrants in France

\begin{tabular}{|c|c|c|c|c|}
\hline $\begin{array}{l}\text { Ref. } \\
\text { Number }\end{array}$ & $\begin{array}{l}\text { Study period, type of } \\
\text { study and study size }\end{array}$ & $\begin{array}{l}\text { Type of data, design } \\
\text { and methods }\end{array}$ & $\begin{array}{l}\text { Migrant groups and } \\
\text { comparison group }\end{array}$ & $\begin{array}{l}\text { Main results for migrants } \\
\text { (i.e. statistically significant) }\end{array}$ \\
\hline 46 & $\begin{array}{l}1989 \\
\text { Population-based interview } \\
\text { survey of a representative } \\
\text { sample of households } \\
\text { (9038 households) }\end{array}$ & $\begin{array}{l}\text { Household budgets, with } \\
\text { details concerning food } \\
\text { expenditure. Indicators of } \\
\text { living standards. } \\
\text { Co-variance analysis with } \\
\text { adjustment for household } \\
\text { size, socio-economic } \\
\text { status and income }\end{array}$ & $\begin{array}{l}\text { Households whose heads } \\
\text { were from North Africa } \\
\text { or Portugal vs. households } \\
\text { whose heads were French }\end{array}$ & $\begin{array}{l}\text { Higher consumption of oil, potatoes, } \\
\text { citrus fruits, bread and milk in both } \\
\text { groups. Lower consumption of pork } \\
\text { and alcohol among North Africans, } \\
\text { and higher consumption of fish and } \\
\text { wine among Portuguese }\end{array}$ \\
\hline 21 & $\begin{array}{l}1986-1987 \\
\text { Population-based interview } \\
\text { survey of a representative } \\
\text { sample of households } \\
\text { (13,147 individuals) }\end{array}$ & $\begin{array}{l}\text { Alcohol consumption, } \\
\text { tobacco use, food } \\
\text { frequency questionnaire }\end{array}$ & $\begin{array}{l}\text { Foreigners born in } \\
\text { Spain/Portugal, Italy or } \\
\text { North Africa vs. people } \\
\text { born with French } \\
\text { nationality }\end{array}$ & $\begin{array}{l}\text { Lower consumption of dairy products } \\
\text { and meat }(\mathrm{OR}=0.4 \text { for North Africans), } \\
\text { higher consumption of starchy food } \\
\text { and legumes (OR }=1.5 \text { for North } \\
\text { Africans). Lower consumption of } \\
\text { alcohol and higher tobacco intake } \\
\text { among North Africans }\end{array}$ \\
\hline
\end{tabular}


of psychiatric disorders, parasitism, tuberculosis, and infections by HIV and hepatitis $\mathrm{C}$ virus are particularly high among migrants ${ }^{25,26}$. Foreigners represent $14 \%$ of the cases of AIDS registered in France between 1978 and 1998; very high incidence rates are found for foreigners from sub-Saharan Africa ${ }^{27}$. The excessive risk in this community could be due to several factors: the high prevalence of HIV infection in the countries of origin, the existence of migration for medical reasons, and a low access to preventive and health care due to cultural and religious barriers, as well as to socio-economic and legal factors $^{27,28}$

The analysis of population-based data leads to quite a different picture. Migrants affiliated with the national social insurance scheme were shown to have on average a better health status than French individuals of the same age $^{25}$. This general under-morbidity has been confirmed for members of households whose heads originated from North Africa, using the data from another national survey $^{29}$. The most striking observation was an important $(-68 \%)$ and significant favourable difference in the prevalence of reported cardiovascular diseases for men from North Africa compared with French men of the same age and occupation type. And yet, North African men were found to smoke as heavily as the local-born in the same occupational categories. Women from the same community were less advantaged in terms of their health in comparison with their French peers: the prevalence of obesity was twice as high, and they were at a significantly higher risk of being diabetic than French women ${ }^{29}$.

\section{Mortality}

The first study on migrant mortality in France showed that the death rates of migrants were unexpectedly low: not only better than the national average, but also better than rates specific to their occupational categories ${ }^{30}$. These findings were subsequently confirmed by an analysis of the mortality data of 35-64 year old adults living in France in 1979-1985, which showed a global and important $(-30 \%)$ reduction in the mortality rate of migrants compared with local-born adults of similar age, occupational status and place of residence ${ }^{31}$. This profile was consistent with morbidity data, since the extent of undermortality was particularly important for men from Portugal and North Africa, and for causes of death such as cancers of the digestive tract $\mathrm{t}^{32,33}$ and cardiovascular diseases ${ }^{34}$. Even after correction for under-registration of deaths, Moroccan men living in France had lower death rates than those in Morocco and also than French nationals, with a life expectancy at birth estimated at 73.7 years, vs. 71.3 for the country as a whole ${ }^{34}$. In contrast, Moroccan women, although in a better position than in their homeland, gained less from migration than men, with a life expectancy at birth estimated as 78.8 years vs. a national figure of 79.4 .

Conversely, migrants from eastern European countries were found to suffer from higher death rates from cardiovascular diseases and diseases of the respiratory and digestive systems, and migrants from West Africa, India, Pakistan and Southeast Asia had higher death rates from infectious and parasitic diseases ${ }^{31}$. Lastly, two mortality studies carried out in the 1980s are worth mentioning: one found a higher mortality from all causes of deaths in 1-24 year old migrants ${ }^{35}$; the other found a higher stillbirth rate among foreign women, especially those born in North Africa ${ }^{24}$. These two findings, however, were not adjusted for socio-economic status.

\section{Dietary practices of migrants in France}

\section{The Mediterranean diet}

The MONICA study at the European level ${ }^{36}$, the Seven Countries Study ${ }^{37}$ and statistics from the WHO and the $\mathrm{OECD}^{38}$ at the international level have shown that populations from the Mediterranean countries (Italy, Portugal, France, Yugoslavia, Greece and Spain) present the lowest death rates from ischaemic heart disease. On one hand, these data are consistent with the protective effects of olive oil ${ }^{39}$, wine or alcohol ${ }^{38}$, and of antioxidants such as vitamin $\mathrm{E}^{36}$ and flavonoids ${ }^{40}$. On the other hand, they point to saturated fats ${ }^{37}$ and animal foods (excluding fish) ${ }^{41}$ as important determinants of mortality by cardiovascular diseases. These ecological observations have also shown inverse relationships between fibre intake and mortality from colorectal cancer ${ }^{42}$, and between carbohydrate intake and total mortality ${ }^{43}$.

As the typical diet found in southern Europe may contribute to low rates of chronic diseases and high adult life expectancy, it has been proposed as a model for healthy eating: abundant consumption of cereals, vegetables and fruits, low consumption of dairy products and red meat, use of olive oil as the principal added fat, and wine in moderation ${ }^{44}$. Less is known about dietary habits in Mediterranean regions other than southern Europe. A recent study suggests, however, that a pattern consisting of a low proportion of energy from fats (15\%), a high proportion of energy from carbohydrates (67\%) and a high polyunsaturated to saturated fatty acids ratio (1.04) exists in North African countries ${ }^{45}$. Another aspect of their dietary practices was that the energy intake was as high among women as men, while in western countries it is consistently lower ${ }^{45}$.

\section{Food consumption}

In France, the large nutritional surveys carried out to date were either restricted to French people or did not separate native people from migrants or foreigners. Some dietary studies have been conducted, however, on specific groups of migrants. The most relevant and comprehensive of these used data from a French national survey of individuals more than 18 years of age living in private households. It was conducted between 1986 and $1987^{21}$. 
Table 4 Overview of potential biases in studies of the mortality of migrants

\begin{tabular}{lll}
\hline Type of bias & Mortality estimation & Impact of bias correction \\
\hline $\begin{array}{l}\text { Under-estimation of the migrants' population size } \\
\text { Migration for medical reasons }\end{array}$ & $\begin{array}{l}\text { Over-estimation of mortality } \\
\text { Over-estimation of mortality } \\
\text { Selection of healthy migrants ('healthy migrant effect') } \\
\text { (relative to country of origin) }\end{array}$ & $\begin{array}{l}\text { Would reinforce migrants' advantage } \\
\text { Would reinforce migrants' advantage } \\
\text { Would reduce migrants' advantage }\end{array}$ \\
$\begin{array}{l}\text { Under-registration of deaths due to return to home country } \\
\text { of severely diseased migrants ('salmon bias') }\end{array}$ & Under-estimation of mortality & Would reduce migrants' advantage \\
\hline
\end{tabular}

The dietary habits of three groups of migrants (Italy, Spain and Portugal, North Africa) were compared with those of French nationals. The findings, after adjustment for age, occupation and place of residence, included evidence for: a lower consumption of meat and dairy products; a higher consumption of cereals and legumes; a greater consumption of fruits (except in North African men and Iberian women); and a higher consumption of fish among Iberian migrants of both sexes. Consistently with the typical Mediterranean diet, Portuguese and North African families have been shown to consume significantly more oil, notably olive oil, potatoes and citrus fruits than French families of similar socio-economic level ${ }^{46}$.

Such dietary patterns differ from the eating behaviour of low-income French people who consume less meat and dairy products than people of higher income, but also less fruits ${ }^{47}$. The data confirm the persistence of specific ethnic or cultural dietary behaviours shown in previous studies of families from Portugal ${ }^{48}$, Asia ${ }^{49}$ and North Africa $^{50}$. These might be rooted in the historical and geographical origins of the migrants. Food prescriptions or proscriptions, such as the rejection of pork and the preference for lamb in North African families or, conversely, the rejection of lamb and the preference for pork in Asiatic families, play a unifying role in the community ${ }^{49}$. In Moslem populations, alcohol prohibition is less respected than pork prohibition, indicating that adherence to some practices is probably based more on cultural than religious factors ${ }^{18}$.

The progressive loss of traditional patterns of eating, known as the 'nutrition transition', has affected various countries during the last decades ${ }^{51}$, including Mediterranean ones ${ }^{52}$. The transition may be more rapid in migrants, due to the large differences existing between their imported habits and the predominant lifestyles in their new environments. In France, as in other European countries $^{53}$, changes to the original culinary cultures are perceptible and are greater among the second generation of migrants ${ }^{49,50,54}$. Breakfasts and snacks are the most acculturated meals, while dinner remains closer to their cultural dietary background. By asserting their preference for simplified dishes or foods, such as pasta, pizzas, fried potatoes and chips, roast chicken and dairy products, children born and schooled in France are mainly responsible for the transition.

\section{Nutritional status}

The nutrient intake of migrants living in France has not been investigated so far. There are some data, however, on their nutritional status, particularly that of children. Most data originate from health centres and are not adjusted for socio-economic factors. Children from North African families are at risk of vitamin D deficiency, even after 10 years of age ${ }^{55}$, notably if they do not come back to their country of origin for holidays ${ }^{56}$. Iron $^{57,58}$ and iodine ${ }^{59}$ deficiencies are highly prevalent in migrant children, particularly in families from sub-Saharan Africa. Anaemia is also more frequent in migrant women than in metropolitan French women at term in pregnancy ${ }^{60}$. Both women $^{29}$ and pre-school girls ${ }^{61}$ of North African origin have a high risk of being obese.

\section{Interpretation of the morbidity and mortality profiles of migrants in relation to their diet}

\section{The migrant mortality paradox}

Based mainly on mortality data, the health status of Mediterranean migrants in France unexpectedly turns out to be somewhat better than that of the local-born population. This paradox is not particular to France, but has also been described in the United States for Latinos ${ }^{7,9}$, in Germany for Turks ${ }^{62}$ and in Sweden ${ }^{63}$, England ${ }^{64}$ and Australia $^{32,65}$ for southern Europeans. Conversely, migrants from eastern Europe living in France experience a higher mortality than the local-born population ${ }^{31}$. In England and Wales, standardized mortality ratios for deaths from all causes are close to the national average for migrants born in southern Asia (Indians), higher for Scotland- and Ireland-born migrants, and lower for Caribbean-born migrants 5 . More or less unfavourable lifestyle habits (for instance, high consumption of alcohol by eastern Europeans in France and high use of tobacco by Scottish and Irish immigrants in England) and duration of residence in the host countries, with progressive acculturation of migrant communities, may account for these differences.

Various biases, summarized in Table 4, may limit the validity of mortality data for migrants in France. Illegal immigration (leading to an under-estimation of the total number of migrants) and immigration for medical reasons (leading to an over-estimation of the number of deaths, at 
least for some specific causes) may induce an overestimation of mortality rates in migrants. Correction of these biases would even reinforce the migrants' health advantage in France.

More importantly, two other biases, which potentially result in an underestimation of the mortality of migrants, may be involved in the migrant mortality paradox. The first, known as the 'healthy migrant effect', is a selection bias comparable to the 'healthy worker effect'. Migrants probably come from the healthier sections of the population of their country of origin, as they are submitted to a positive selection, either via self-selection or a selection related to mandatory health controls at entrance. This would be consistent with the finding of a more limited health advantage in women than in men, the latter generally migrating as workers and the former for familial reunification. The second bias, known as the return bias (or 'salmon bias' in Ref. 9), refers to deaths occurring in the country of origin and therefore going unregistered in the host country. Migrants may not officially declare their return to their home country when struck down by a chronic or invalidating disease, or to keep the advantage of an allowance granted in the host country ${ }^{63}$. Recent analyses from other countries suggest that this type of bias, although present, is not likely to change the general pattern of the results ${ }^{9,63}$. In France, the under-registration of deaths of migrants from Morocco has been estimated to be as high as 30\%. Even after correction for this under-registration, life expectancy remained higher and mortality rates by cancer and cardiovascular diseases lower in Moroccans than in the French $^{34}$. For Portuguese also, the magnitude of the mortality difference was too large $(-60 \%)$ to be attributable entirely to the under-registration bias ${ }^{31}$.

Evidence of health benefits linked to migration are particularly noticeable for those diseases known as diseases of affluence, which are associated with physical inactivity and with occidental diets. In addition, among migrants living in France, only those originating from Mediterranean countries shared these advantages, which strongly suggests that environmental factors are involved in the paradox. We will now examine the possibility that healthy dietary patterns might explain the relatively good health of Mediterranean migrants in France. Men, women and children will be considered separately, as well as migrants not living in private households.

\section{Men}

A very high risk of mortality by thyroid diseases was observed in migrants from Algeria (and eastern Europe) ${ }^{31}$, which could be related to low iodine intake during the years they lived in their country of origin ${ }^{66}$. Apart from that, an under-mortality was observed in Mediterranean men for nearly all causes of death that may be related to nutrition, such as endocrine, metabolic and cardiovascular diseases, as well as digestive cancers. Migrants originating from Italy ${ }^{32}$ and North Africa ${ }^{33}$ presented a lower mortality from colorectal cancers, and Moroccans ${ }^{34}$ and Portuguese ${ }^{31}$ were well protected from digestive and cardiovascular diseases. Consistent with the lower consumption of alcohol by migrants from North Africa ${ }^{21}$, their mortality from hepatic cirrhosis was also $\operatorname{low}^{31}$. In addition, despite a tobacco intake at least as high as that of French men of the same socio-economic level ${ }^{29}$, migrants from North African countries had a lower mortality from smoking-related cancers ${ }^{31,34}$. Altogether, these data suggest that, in addition to the healthy migrant effect, environmental factors and lifestyles, such as the traditional eating patterns which are maintained by men originating from southern Europe and North Africa may protect them from chronic diseases.

\section{Women}

North African women do not present the same health advantage as men $^{29}$. Various factors may explain this difference. First, most of the migrant women did not arrive in France as workers, and therefore they were not submitted to the positive selection linked to the working immigration. Second, North African women are more often non-working than are local-born women of similar socio-economic status ${ }^{46}$, and are therefore less likely than men to have regular medical check ups. Third, North African women are more frequently obese than French women of the same age and social background ${ }^{29}$.

In most developed societies including France, ethnic differences in the prevalence of obesity ${ }^{67,68}$ and an inverse relationship between obesity and socio-economic status ${ }^{69-71}$ are particularly noticeable in women, but not in men. On one hand, women of all races have a higher prevalence of obesity than men because a number of physiological processes contribute to an increased storage of fat in females ${ }^{72}$. On the other hand, it appears that several ethnic groups in industrialized countries are more prone to obesity: this may be due to a genetic predisposition which only becomes apparent once the individuals are suddenly exposed to a more affluent lifestyle $\mathrm{e}^{72,73}$. Consequently, the risk is particularly high in women from ethnic minorities living in industrialized countries $^{72,74}$.

The increased risk of morbidity ${ }^{29}$ and mortality ${ }^{34}$ by endocrine diseases, particularly diabetes mellitus, observed in North African women living in France is consistent with their increased susceptibility to obesity ${ }^{72}$ and to a less stringent medical follow-up of diabetes in migrants $^{75}$. There was less evidence, however, of a parallel increase in the risk of cardiovascular diseases in these women ${ }^{29,34}$. In fact, there are conflicting reports on whether obesity confers similar cardiovascular and coronary heart disease risks in different ethnic groups ${ }^{76,77}$. Ethnic differences in the relationship between body mass index and percent body $\mathrm{fat}^{78}$ or central distribution of adipose tissue ${ }^{79}$, might explain these controversies. 
Although adjustment for occupational status of the family head was made ${ }^{29}$, the high prevalence of obesity found in North African women in France might be related to other socio-economic factors known to be associated with obesity, such as urban (vs. rural) place of residence, and lower levels of education and/or income ${ }^{72}$. Their non-working status ${ }^{46}$, associated with the tradition of women remaining within the home in Muslim cultures, might limit their level of physical activity and induce obesity. In addition, the lack of difference in energy intake between men and women in North Africa ${ }^{45}$ suggests that North African women are less subject than European women to negative social pressure regarding ideal weight. In fact, in many traditional cultures, increased weight and girth are viewed as a sign of health and prosperity ${ }^{72}$. Accordingly, it has been observed in the United Kingdom ${ }^{80}$ and in the $\mathrm{USA}^{81}$ that women from ethnic minorities are less likely to rate themselves as overweight and to diet. Despite these high rates of obesity, there was a global and significant diminution $(-16 \%)$ in disease prevalence in North African compared with local-born women in France ${ }^{29}$. Their traditional patterns of eating ${ }^{21}$ and the low proportion of smokers among them ${ }^{29}$ might explain such a global protection.

\section{Children}

North American studies have shown that the risks of both obesity $^{82}$ and nutrient deficiencies, especially iron deficiency $^{83}$, are higher in pre-school children at the lower end of the socio-economic spectrum. Therefore, it can be argued that the nutritional risks observed in migrant children living in France, namely nutrient deficiencies ${ }^{55-58}$ and obesity ${ }^{61}$, are only related to the low social status of their parents. However, other factors, more specific to their position as migrants also need to be looked at. Higher risks for vitamin D deficiency in migrant children might be related to insufficient sun exposure linked to cultural habits and a low rate of endogenous synthesis when the skin is highly pigmented. Iron deficiency might be partly explained by intestinal dysfunction secondary to intestinal infections, alactasia, gluten intolerance, or lead poisoning, possibly more frequent, or more frequently undiagnosed, in migrant children. In addition, the introduction of weaning foods is delayed in migrant children $^{84,85}$, and weaning diets may have a high phytateto-iron molar ratio, possibly inducing iron deficiency.

More importantly, cultural and language barriers might limit access to dietary information. Because they do not strictly follow the mandatory preventive care of their children $^{22}$, migrant families would have less access to preventive dietary advice for children, such as fluoride supplementation and the use of iron and vitamin D fortified milk formula. Lastly, the accelerated dietary transition observed in this young population might be involved in the high frequency of obesity observed in North African children ${ }^{61}$.
Institutionalized and lonely migrants

The proportion of people not living in private households (i.e. living in collective shelters, institutions, mobile housing, etc.) has been estimated to be $5 \%$ among migrant populations, which is higher than the $2 \%$ found in the general population ${ }^{86}$. However, nothing is known about the dietary habits or nutritional status of institutionalized and/or lonely migrants. Some physicians have reported difficulties in feeding hospital patients from Africa because of cultural barriers ${ }^{87}$. The difficult situation of elderly male migrants living alone and disconnected from their home country is beginning to receive attention from demographers and sociologists ${ }^{13,18}$. These migrants often live in extremely precarious conditions and in great social isolation, which might lead to malnutrition.

\section{Conclusion}

Given the socio-economic profile of migrants in France and their limited utilization of preventive health services, they are expected to be at higher risk of diseases than the local-born population. Paradoxically, Mediterranean migrants stand out as having better health than the local born, suggesting that very efficient protective factors are operating in this population. The present review has shown that these migrants have dietary patterns quite close to some of the recommendations recently set up in the National Programme on Nutrition and Health coordinated by the French 'Haut Comité de la Santé Publique', namely a high consumption of fruits and starchy products and low consumption of alcohol ${ }^{88}$.

The Mediterranean pattern of eating might protect adults from chronic diseases. However, it is likely that the second generation of migrants will lose the advantages provided by their cultural background as they rapidly adopt a more occidental diet. A better knowledge of food and nutrient intakes of North Africans living in France, in relation to their health status, is clearly needed as it may provide clues for designing nutritional education campaigns, particularly those aimed at low-income people. Both population-based nutritional surveys and in-depth surveys of the food habits of migrant communities would be very useful in this respect.

\section{Acknowledgements}

The authors wish to thank Dr A. Ferro-Luzzi and Dr S. Hercberg for initiating this work and Dr E. Ferguson for editorial assistance.

\section{References}

1 Moradi T, Delfino RJ, Bergström SR, Yu ES, Adami HO, Yuen J. Cancer risk among Scandinavian immigrants in the US and Scandinavian residents compared with US whites, 1973-89. Eur. J. Cancer Prev. 1998; 7: 117-25.

2 McCredie M, Williams S, Coates M. Cancer mortality in East 
and Southeast Asian migrants to New South Wales, Australia, 1975-1995. Br. J. Cancer 1999; 79: 1277-82.

3 Kunst AE, Groenhof F, Mackenbach JP, Health EW. Occupational class and cause specific mortality in middle aged men in 11 European countries: comparison of population based studies. EU Working Group on Socioeconomic Inequalities in Health. BMJ 1998; 316: 1636-42.

4 Schrijvers CT, Stronks K, van de Mheen HD, Mackenbach JP. Explaining educational differences in mortality: the role of behavioral and material factors. Am. J. Public Health 1999; 89: $535-40$.

5 Wild S, McKeigue P. Cross sectional analysis of mortality by country of birth in England and Wales, 1970-92. BMJ 1997; 314: 705-10.

6 Markides KS, Coreil J. The health of Hispanics in the southwestern United States: an epidemiologic paradox. Public Health Rep. 1986; 101: 253-65.

7 Scribner R. Paradox as paradigm - the health outcomes of Mexican Americans [editorial; comment]. Am. J. Public Health 1996; 86: 303-5.

8 Sharma S, Cade J, Griffiths S, Cruickshank K. Nutrient intakes among UK African-Caribbeans: changing risk of coronary heart disease. Lancet 1998; 352: 114-5.

9 Abraído LA, Dohrenwend BP, Ng MD, Turner JB. The Latino mortality paradox: a test of the 'salmon bias' and healthy migrant hypotheses. Am. J. Public Health 1999; 89: 1543-8.

10 Parkin DM, Khlat M. Studies of cancer in migrants: rationale and methodology. Eur. J. Cancer 1996; 32: 761-71.

11 Haut Comité de la Santé Publique. Rapport du HCSP au Ministère de l'Emploi et de la Solidarité, editor. La progression de la précarité en France et ses effets sur la santé. 1998.

12 Labat J. La population étrangère en 1990 par nationalité. Insee Première 1992; 217: 1-4.

13 Mesrine A, Thave S. Vieillir en France quand on est immigré. In: INSEE, eds. Données Sociales: La Société Française. INSEE, 1999: 28-35.

14 Desplanques G, Tabard N. La localisation de la population étrangère. Econ. Stat. 1991; 242: 51-61.

15 Willard J. Conditions d'emploi et salaires de la main-d'oeuvre étrangère. Econ. Stat. 1984; 162: 15-27.

16 Maurin E. Les étrangers: une main d'oeuvre à part? Econ. Stat. 1991; 242: 39-50.

17 Thave S. Les étrangers et leurs logements. Insee Première 1999; 689: 1-4.

18 Tribalat M. De l'immigration à l'assimilation. La Découverte/ INED edition, 1995.

19 Echardour A. Les jeunes d'origine portugaise, immigrés ou enfants d'immigrés. Insee Première 1996; 427: 1-4.

20 Firdion J, Marpsat M, Mizrahi A. Vie et Santé des personnes sans domicile à Paris. Bull. Inf. Econ. Santé (Credes) 1998; 13: $1-4$.

21 Wanner P, Khlat M, Bouchardy C. Habitudes de vie et comportements en matière de santé des immigrés de l'Europe du Sud et du Maghreb en France [Life style and health behavior of southern European and North African immigrants in France]. Rev. Epidémiol. Santé Publique 1995; 43: 548-59.

22 Lehingue Y, Fassio F, Momas I, Daures JP. Surveillance épidémiologique des enfants des écoles maternelles de l'Hérault lors des bilans de santé du service de protection maternelle et infantile [Epidemiologic surveillance through five clinic screenings of children in the Herault]. Rev . Epidemiol. Santé Publique 1992; 40: 25-32.

23 Kaminski M, Blondel B, Breart G, Franc M, du MC. Issue de la grossesse et surveillance prénatale chez les femmes migrantes [Outcome of pregnancy and prenatal care among immigrant women]. Rev. Epidémiol. Santé Publique 1978; 26: $29-46$.

24 Saurel CM, Stengel B, Kaminski M, Blondel B. Surveillance prénatale et issue de la grossesse selon l'origine des femmes nées hors de France métropolitaine [Prenatal surveillance and outcome of pregnancy according to the origin of women born outside continental France]. J. Gynecol. Obstet. Biol. Reprod. 1986; 15: 19-27.

25 Mizrahi A, Mizrahi A, Wait S, CREDES, eds. Accès aux soins et état de santé des populations immigrées en France. Report No. 968. Paris, 1993.

26 Brücker G, Nguyen DT, Lebas J. L'accès aux soins des personnes démunies à l'Assistance Publique-Hopitaux de Paris [Access to health care for destitute persons at Public Assistance Hospitals in Paris]. Bull. Acad. Natl. Med. 1997; 181: 1681-97.

27 Savignoni A, Lot F, Pillonel J, Laporte A. Institut de Veille Sanitaire. Situation du SIDA dans la population étrangère domiciliée France - depuis le début de l'épidémie jusqu'en Juin 1998. Bull. Epidemiol. Hebdo. 1999; 27: 1-7.

28 CRIPS. Rapport du Centre Régional d'Information et de Prévention du Sida de Provence-Alpes Cote d'Azur, ed. Migrants et VIH, 1999.

29 Khlat M, Sermet C, Laurier D. La morbidité dans les ménages originaires du Maghreb sur la base de l'enquête Santé de l'Insee. Population 1998; 6: 1155-84.

30 Brahimi M. La mortalité des étrangers en France. Population 1980; 3: 603-22.

31 Wanner P, Bouchardy C, Khlat M. Causes de décès des immigrés en France 1979-1985. Migrations Santé 1997; 91 9-38.

32 Khlat M. Cancer in Mediterranean migrants - based on studies in France and Australia. Cancer Causes and Control 1995; 6: 525-31.

33 Bouchardy C, Parkin DM, Wanner P, Khlat M. Cancer mortality among North African migrants in France. Int. J. Epidemiol. 1996; 25: 5-13.

34 Courbage Y, Khlat M. Mortality and causes of death of Moroccans in France, 1979-1985. Population: An English selection. Population 1996; 8: 59-94.

35 Bouvier-Colle M, Magescas JHF. Causes de décès des jeunes étrangers en France [Causes of death among young foreign people in France]. Rev. Epidémiol. Santé Publique 1985; 33 409-16.

36 Gey KF, Puska P, Jordan P, Moser UK. Inverse correlation between plasma vitamin $\mathrm{E}$ and mortality from ischemic heart disease in cross-cultural epidemiology. Am. J. Clin. Nutr. 1991; 53: 326S-34S.

37 The diet and all-causes death rate in the Seven Countries Study. Lancet 1981; 2: 58-61.

38 Renaud S, de Lorgeril M. Wine, alcohol, platelets, and the French paradox for coronary heart disease. Lancet $1992 ; 339$ : 1523-6.

39 Keys A, Menotti A, Karvonen MJ, Aravanis C, Blackburn H, Buzina R, et al. The diet and 15-year death rate in the seven countries study. Am. J. Epidemiol. 1986; 124: 903-15.

40 Hertog MG, Kromhout D, Aravanis C, Blackburn H, Buzina R, Fidanza F, et al. Flavonoid intake and long-term risk of coronary heart disease and cancer in the seven countries study. Arch. Intern. Med. 1995; 155: 381-6.

41 Menotti A, Kromhout D, Blackburn H, Fidanza F, Buzina R, Nissinen A. Food intake patterns and 25-year mortality from coronary heart disease: cross-cultural correlations in the Seven Countries Study. The Seven Countries Study Research Group. Eur. J. Epidemiol. 1999; 15: 507-15.

42 Jansen MC, Bueno dMH, Buzina R, Fidanza F, Menotti A, Blackburn $\mathrm{H}$, et al. Dietary fiber and plant foods in relation to colorectal cancer mortality: the Seven Countries Study. Int J. Cancer 1999; 81: 174-9.

43 Farchi G, Fidanza F, Grossi P, Lancia A, Mariotti S, Menotti A. Relationship between eating patterns meeting recommendations and subsequent mortality in 20 years. Eur. J. Clin. Nutr. 1995; 49: 408-19.

44 Willet W, Sacks F, Trichopoulou A, Drescher G, Ferro-Luzzi 
A, Helsing E, et al. Mediterranean diet pyramid: a cultural model for healthy eating. Am. J. Clin. Nutr. 1995; 61: 1402S$6 \mathrm{~S}$.

45 Ghannem H, Hadj FA. Habitudes alimentaires et facteurs de risque cardiovasculaire [Eating habits and cardiovascular risk factors. Epidemiologic study of the Tunisian Sahel]. Presse Med. 1999; 28: 1005-8.

46 Moutardier M. Les conditions de vie des étrangers se sont améliorées depuis dix ans. Econ. Stat. 1991; 242: 69-82.

47 Michaud C, Baudier F, Loundou A, Le Bihan G, Janvrin MP, Rotily M. Food habits, consumption, and knowledge of a low-income French population. Santé Publique 1998; 10: 333-47.

48 Cohen M, Soares L, Mordelles A. Quelques observations sur l'alimentation des enfants de travailleurs migrants d'origine portugaise. Cah. Nutr. Diet. 1977; 14: 19-23.

49 Raulin A. Concommation et adaptation urbaine des minorités en région parisienne. Soc. Contemporaines 1990; 4: 19-36.

50 Mabe B. Comportement alimentaire et migration ou 'le changement dans la continuité'. Migrations Santé 1985; 43: 11-6.

51 Popkin BM. The nutrition transition in low-income countries: an emerging crisis. Nutr. Rev. 1994; 52: 285-98.

52 Helsing E. Trends in fat consumption in Europe and their influence on the Mediterranean diet. Eur. J. Clin. Nutr. 1993; 47 (Suppl. 1): S4-12.

53 Sharma S, Cade J, Riste L, Cruickshank K. Nutrient intake trends among African-Caribbeans in Britain: a migrant population and its second generation. Public Health Nutr. 1999; 2: 469-76.

54 Calvo M. Migration and alimentation. Soc. Sci. Inf. 1982; 21: 383-446.

55 Colmant A, Freycon MT, Serio AM, Durr F, Frederich A, Freycon F, et al. Plasma 25-OH D deficiency in Maghrebian children more than 10 years of age immigrated to France. Pediatrie 1985; 40: 17-25.

56 Guy C, Annino MC, Danis C, Durr F, Frederich A. Etude de la 25-hydroxyvitamine D chez des enfants de 3 à 6 ans suivis en consultation de protection maternelle et infantile [Study on 25-hydroxyvitamin D in children 3 to 6 years old followed at the Service de Protection Maternelle et Infantile]. Pediatrie 1986; 41: 205-14.

57 Mekki N, Galan P, Rossignol C, Farnier MA, Hercberg S. Le statut en fer chez l'enfant de 10 mois, 2 ans et 4 ans présumé bien-portant [Iron status in presumably healthy children 10 months, 2 years and 4 years of age]. Arch. Fr. Pediatr. 1989; 46: 481-5.

58 Mahiou C, Frappaz D, Freycon MT, Freycon F. Iron deficiency in infants and children. Pediatrie 1992; 47: 551-5.

59 Valeix P, Preziosi P, Rossignol C, Farnier MA, Hercberg S. Relationship between urinary iodine concentration and hearing capacity in children. Eur. J. Clin. Nutr. 1994; 48 : 54-9.

60 Hercberg S, Wainer R, Bard D, Soustre Y, Galan P. Study of the iron status of a population of pregnant women. Rev. Fr. Gynecol. Obstet. 1985; 80: 467-72.

61 Rovillé SF. Evolution en 20 ans de la corpulence des enfants de 0 à 4 ans issus de l'immigration maghrébine [Increase during the last 20 years of body mass of children 0 to 4 years of age born to Maghrebian immigrants]. Rev. Epidémiol. Santé Publique 1999; 47: 37-44.

62 Razum O, Zeeb H, Akgün H, Yilmaz S. Low overall mortality of Turkish residents in Germany persists and extends into a second generation: merely a healthy migrant effect? Trop. Med. Int. Health 1998; 3: 297-303.

63 Weitof G, Gullberg A, Hjern A, Rosen M. Mortality statistics in immigrant research: method for adjusting underestimation of mortality. Int. J. Epidemiol. 1999; 28: 756-63.

64 Marmot MG, Adelstein AM, Bulusu L. Lessons from the study of immigrant mortality. Lancet 1984; 1: 1455-7.
65 Powles J. The best of both worlds: attempting to explain the persisting low mortality of Greek migrants to Australia. In: The Australian National University HTC, eds. What we Know about Health Transition: The Cultural, Social and Behavioural Determinants of Health. Canberra, Australia: The Australian National University, 1990: 584-894.

66 Bachtarzi H, Benmiloud M. TSH-regulation and goitrogenesis in severe iodine deficiency. Acta Endocrinol. (Copenhagen) 1983; 103: 21-7.

67 Cappuccio FP, Cook DG, Atkinson RW, Strazzullo P. Prevalence, detection, and management of cardiovascular risk factors in different ethnic groups in south London. Heart 1997; 78: 555-63.

68 Flegal KM, Carroll MD, Kuczmarski RJ, Johnson CL. Overweight and obesity in the United States: prevalence and trends, 1960-1994. Int. J. Obes. Relat. Metab. Disord. 1998; 22: 39-47.

69 Buemann B, Tremblay A, Bouchard C. Social class interacts with the association between macronutrient intake and subcutaneous fat. Int. J. Obes. Relat. Metab. Disord. 1995; 19: $770-5$.

70 Sobal J, Stunkard AJ. Socioeconomic status and obesity: a review of the literature. Psychol. Bull. 1989; 105: 260-75.

71 Ziegler O, Drolez B, Siest G, Guéguen R. Relationship between body mass index and socioeconomic status: the RMI family study. Int.J. Obes. Relat. Metab. Disord. 1998; 22: S244.

72 World Health Organization. Obesity: preventing and managing the global epidemic. Report of a WHO consultation on Obesity, 1997.

73 Neel JV, Weder AB, Julius S. Type II diabetes, essential hypertension, and obesity as 'syndromes of impaired genetic homeostasis': the 'thrifty genotype' hypothesis enters the 21st century. Perspect. Biol. Med. 1998; 42: 44-74.

74 Solomon CG, Manson JE. Obesity and mortality: a review of the epidemiologic data. Am. J. Clin. Nutr. 1997; 66: 1044S$50 \mathrm{~s}$.

75 Obadia G, Lombrail P, Thibult N, Eschwege E, Passa P. Prise en charge hospitalière du diabète insulino-traité chez les immigrés Africains en France [Hospital care of insulin-treated diabetes in African immigrants, in France]. Diabete Metab. 1986; 12: 16-20.

76 Stevens J, Plankey MW, Williamson DF, Thun MJ, Rust PF, Palesch Y, O'Neil PM. The body mass index-mortality relationship in white and African American women. Obes. Res. 1998; 6: 268-77.

77 Folsom AR, Stevens J, Schreiner PJ, McGovern PG. Body mass index, waist/hip ratio, and coronary heart disease incidence in African Americans and whites. Atherosclerosis Risk in Communities Study Investigators. Am. J. Epidemiol. 1998; 148: 1187-94.

78 Deurenberg P, Yap M, van Staveren WA. Body mass index and percent body fat: a meta analysis among different ethnic groups. Int. J. Obes. Relat. Metab. Disord. 1998; 22: $1164-71$.

79 Bose K. A comparative study of generalised obesity and anatomical distribution of subcutaneous fat in adult white and Pakistani migrant males in Peterborough. J. R. Soc. Health 1995; 115: 90-5.

80 Pomerleau J, McKeigue PM, Chaturvedi N. Factors associated with obesity in South Asian. Afro-Caribbean and European women. Int. J. Obes. Relat. Metab. Disord. 1999; 23: 25-33.

81 Stevens J, Kumanyika SK, Keil JE. Attitudes toward body size and dieting: differences between elderly black and white women. Am. J. Public Health 1994; 84: 1322-5.

82 Mei Z, Scanlon KS, Grummer SL, Freedman DS, Yip R, Trowbridge FL. Increasing prevalence of overweight among US low-income preschool children: the Centers for Disease Control and Prevention pediatric nutrition surveillance, 1983 to 1995. Pediatrics 1998; 101: 1-6. 
83 Rose D, Habicht JP, Devaney B. Household participation in the Food Stamp and WIC programs increases the nutrient intakes of preschool children. J. Nutr. 1998; 128: 548-55.

84 Saurel CM. Situation des femmes nées en Afrique Noire ayant accouché en France en 1981: surveillance prénatale, accouchement et santé de l'enfant à la naissance. Migrations Santé 1985; 44: 20-3.

85 Chauliac M, Chateil S. Nutrition et alimentation des enfants en bas âge (6 à 36 mois) de familles défavorisées. Med. Nutr. 2000; 36: 13-24.

86 Tribalat M. Les immigrés au recensement de 1990 et les populations liées à leur installation en France. Population 1993; 6: 1911-46.

87 Ben Slama, L, Association Nord-Sud Solidaires, eds. Nutrition, urbanisme et immigration. Projet d'enquête nutritionnelle dans le quartier des Tarterêts, 1999.

88 Groupe de travail réuni par le Haut Comité de la Santé Publique. Chapitre 6. Les objectifs nutritionnels prioritaires de santé publique et les objectifs spécifiques. In: Pour une politique nutritionelle de santé publique en France. Enjeux et propositions. Collection Avis et Rapports, ENSP eds, Rennes (France) Juin 2000: 189-95. 